\title{
Warpreneurship: War as a Business
}

\author{
Gerald Peter Mutonyi ${ }^{1}$
}

${ }^{1}$ Kenyatta University

P. 0. Box 43844-00100, Nairobi, Kenya

DOl: $10.22178 /$ pos.74-11

JEL Classification: K40

Received 22.08.2021

Accepted 27.09.2021

Published online 30.09.2021

Corresponding Author:

mutonyig@gmail.com

(C) 2021 The Author. This article is licensed under a Creative Commons Attribution 4.0 License @) (1)

\begin{abstract}
Making profits out of war is an ancient phenomenon. There are enterprises constantly supplying material to prepare armies and consequently profit from war. Enterprises have become aware that war itself and the post-war period is undoubtedly lucrative. However, the war also never works for any individual or group, except a dominant elite few: the wealth who propagate and influence patriotic and despotic war-peddling all over the world, making trillions of dollars in profit out of devastations and deaths, at the same time exciting their nationalism, and inspiring the citizen's backing. The paper has examined Executive Outcomes (a commercial security firm) and the United States of America, Russia, Kenya and Uganda as countries that are examples of those engaging in Warpreneurship. But in the long run, the war in itself does not result in peace but immense profits and securing resources for the dominant elite few.
\end{abstract}

Keywords: war; entrepreneurship; warpreneurship; axis of virtuous.

\section{INTRODUCTION}

Since militaries are legitimate, people perceive warfare to be tolerable and do not feel that it is wicked or wrong. Whether their intention is for defence or offence, these enormous influential establishments endure especially to exterminate people. War and large military establishments are the most significant sources of violence in the world [40]. Its very nature is solitary of disaster and misery. People should all be horrified by the extent of their disaster but instead are too confused [40]. This might be because wars have been coated as going to bring peace and security. Examples of such include the majority of Saudi citizens' stance regarding their military involvement in Yemen, the Soviet citizen's attitude concerning their nation's involvement in Syria, and the USA allies' citizen's position regarding their country's participation in Afghanistan and Iraq.

War never breaks out wholly unexpectedly, nor can it be spread instantaneously. Weapons and military have to be accumulated to wage wars. Therefore, the weapons businesses must adopt the entrepreneurial skills of willing to bear the risk of a new war if there is a significant chance for revenue [28]. Making profits out of warfare is a very long-standing reality as there are always firms supplying hardware to prepare militaries and consequently profit from war [28]. Conse- quently, this paper sets out to confirm that contemporary wars never work for any nation, except the weapons entrepreneurs. On the contrary, they will propagate and influence patriotic and racial war-soliciting the whole world, making big dollars in profits from annihilations and destructions while exciting their nationalism and inspiring citizens' backing.

\section{RESULTS AND DISCUSSION}

\section{Old Wars}

For warfare to erupt amongst sane players, notably, one of the actors associated should expect achievements from the skirmish outweighing the expenses incurred. In the absence of this qualification, there is a surety of enduring peace [26]. For instance, it is possible that two nations are individually positive and persuaded that they would achieve advancement from a conflict. In such instances, war can flare up as long as the contradiction of opinions is significant enough to pay off war's cost. For instance, if both states expect to triumph in a war with high enough probability, there would not be any agreement that avoids war [19].

Two examples of wars that are recognised to such blunders or miscalculations due to a lack of 
data about comparative power have been discussed. In 1866, Austria supposed that it was mightier than Prussia, and Prussia believed it superior to Austria. Each was aware of the other's opinion, but they believed it was mistaken [38]. In this case, nationalism triumphed, and Prussia achieved domination over the newly ordered confederation of North Germany, a union of 21 smaller German political units and Prussia [39].

The 1st World War commenced on July 28 1914, and it was blamed on the divergences in policies, even though what ignited it was the murder of Austria's Archduke Franz Ferdinand [2]. The warfare commenced primarily due to four aspects: Patriotism, Alliances, Imperialism and Militarism. In 1914, England predicted that the conflict would be brief as it based its point of view primarily on economics. Then England was the dominant commercial authority. For that reason, if the commercial breakdown were going to hit sooner during the war, it would first affect Germany, leading to its submission [38]. In contradiction, the German rulers anticipated that the conflict would be shortened due to modernised armed forces innovations [38]. Germany was the recognised master in that field and so could expect victory. Expectations of the conclusion of the war had a solid and subjective line of thought. Nationalism and commitment to a treaty saw Britain enter the war [2]. These old wars were fought for geopolitical interests and ideologies, i.e., socialism or democracy.

World War two started on September 1 1939, due to the Treaty of Versailles that was having a crippling effect on the German economy. Germans were outraged and appalled towards their government's acceptance of such a treaty [13]. This appalling sentiment would in the future evolve to resentment feelings of other European states who drafted the treaty and of the administration that acknowledged it. This was a nationalistic war for the people and the nation.

Japan was severely affected by commercial desolation, and its citizens lacked confidence in the state [4]. Therefore, the citizens obligated the military for a solution to be found for their economic difficulties. Consequently, the Japanese military attacked China, a territory endowed with mineral deposits and other resources. This was to get natural resources for its factories to produce more goods that it needed. This, too, was a war for the people and the nation.
As for 1950-1953, Korean War began when the North Communist Korean military went over the 38th parallel and launched an attack on the South non-communist Korea. It has been documented that the Korean war had its origins from a composite of an outer dispute of the USA and USSR policies concerning the East-Asia, and the internal struggles in the Korean peninsula [28]. This context expounds how the Korean peninsula war, although at the outset was a kind of nationalism conflict, ultimately established into a conflict amongst the East and West alliances (cold war).

The Arab-Israeli War of October 6 1973, popularly referred to as the Yom Kippur War, had its conception sown in Israel's spectacular six-day triumph in the 1967 conflict. The Arab militaries endured a humbling loss, which the Egyptian President Nasser felt the most [10]. President Anwar Sadat, who succeeded President Nasser, had a clear diplomatic objective, land for peace, translated into a limited military mission.

The Soviet invasion of Afghanistan in 1979 had a clear political objective as Moscow could not envisage losing their political dominance in a neighbouring patron nation. It was an apprehension reinforced by the suspicions that Islamic fundamentalism would likely diffuse into their Muslim borders [12]. These are only a few 'real' wars that have been fought over nationalism ideologies. Mueller, in other words, refers to them as 'old war' [27]. These old wars were fought for geopolitical interests and ideologies.

\section{The 20th Century Global System}

But then, the international system has undergone a profound transformation in recent years. A transformation moulded by the conclusion of the Cold War in 1990, the globalisation phenomena and the development of fresh arrangements of collaboration and struggle amongst nations and non-nation players. Moreover, through the UN and Regional Organizations, states are in communication with one another [28]. The global arrangements during the 20th century were therefore formulated to brave the inter-state competitiveness and civil skirmishes. Nonetheless, skirmishes and wars have not been eradicated. But due to the achievements in decreasing inter-state conflicts by the current global systems, the leftover practices of skirmishes cannot suit accurately within "war" [44]. 
Most of what passes as wars in the current world are typically symbolised by the evil and innovation competition by 'thugs' and never in any way by the elemental collision of cultures [28]. Most of the agents give justification of ideological rhetoric or national ethnic to give credence to their actions since expressing their thrill for profit would be politically improper [28]. This is because, in the makeup of the 20th-century global system, the United Nations and its subsidiaries have so often been called upon to avert disputes from escalating into war.

This transformation has produced the growth of a new kind of war that is unique from previous ones. Different wars were established in the last years of the 20th century, particularly in Eastern Europe and Africa [21]. These different types of conflicts have been designated by a concept 'New Wars'. The new wars have provoked scholars to re-evaluate the characteristics of warfare from very new dimensions, of the players involved and their interests. The number of intrastate wars has diminished, whereas the frequency of interstate wars has heightened. Therefore, these conflicts are termed internal conflicts or civil wars [21]. From the new perspective, these civil wars or internal conflicts are exclusively engaged in by the non-state players, inspired mainly by financial gains, and that they are ruthless than the previous wars [25].

Some studies have identified ethnic, religious or tribal identities as the most significant variable in analysing wars [14]. Nevertheless, scholars state that the association between wars and ethnic, religious or tribal identities is not natural and social identities are merely vital as a collation scheme in civil wars [11]. At the same time, some of them have been baptised as the war on terror.

One of the best ways to improve and preserve power and funding for war is to keep the populace in constant fear by invoking ethnic, religious or tribal identities and, more recently, of 'terrorism and terrorists'. This enables those at the top of the dominant elite few to easily direct their subjects' thinking and, therefore, shape the world they control. As a result, the populace consents to a more significant part of taxes being spent on financing the endless military-industrial entrepreneurship.

\section{Entrepreneurship}

Business prospects continue being there, but contests are now as much about persistence as development. And, as worldwide contests endure to intensify, opportunities of the market edge are becoming ever more challenging to preserve over some duration of time. Hence it is the capability to form fresh opportunities of market leverage quickly, often that will prove to be the only viable opportunity of real market leverage. Businesses have reacted to adjustments quickly, just as they have responded quickly to the activities of their competitors [6]. Therefore, businesses must adopt the entrepreneurial skills of willing to bear the risk of a new endeavour if there is a significant chance for revenue.

An entrepreneur's role, therefore, is to market their innovations. They develop new merchandise or services that the market demands, and sometimes the market does not demand but are currently not being delivered. Hence, entrepreneurship can be defined as "an analysis of how, by whom and with what consequences opportunities to produce future goods and services are discovered, evaluated and exploited" [33]. Also, an entrepreneur is innovative, first perceiving and creating new opportunities; second operating under unpredictability, as well as introducing merchandises for sell, deciding on the venues, and forming and using means/assets; and third managing their corporation and competing with the rest for a stake of the market [42]. By so doing, these same corporations get to be operational again: building, producing, and marketing again.

Therefore, enterprises have become aware that war itself and the post-war period is undoubtedly lucrative. Weapons and security producing enterprises manufacture all the stockpiles of war that they wish to market for earnings. Therefore, most of it is delivered to their potential consumers and the stockpiles are gotten rid of. Now those prospective buyers: governments and militias have their stocks full, which they paid using taxes or other activities like ransoms and drug peddling. For that reason, they have to justify the rationale for acquiring the battle arsenals to the citizens or themselves. This is through wars and wars that have to be sanitised by the populace and their supporters.

War never works for any individual or group, but for only a dominant elite few: the wealthy who propagate and influence patriotism and ethnic war-peddling worldwide, making big dollars in earnings from devastations and death, while inspiring the citizen's backing [27]. Making earn- 
ings out of warfare is a very age-old phenomenon, as there have been organisations delivering weapons to ready militaries and subsequently earn from wars.

\section{Warpreneurship}

The chance of a civil war occurring in developing countries with dependency on exporting natural resources is much higher than in developing countries that do not have natural resources or are not dependent on exporting this [32]. This is because intrastate wars are primarily fought over resources (even though the public is misled by other motives, such as the threat of 'terrorist attacks, to cover up motives of securing resources and making a profit).

Executive Outcomes (EO), a commercial, military organisation, performed its first critical security expedition in Angola in 1993. The organisation was contracted to represent the Angolan state by Anthony Buckingham, a high-ranking consultant to numerous North American oil firms [3]. Their mission was to retake and secure oil reserves from UNITA rebels, an undertaking that EO completed with precision. The EO's exemplary performance gave rise to a $\$ 40$ million deal with the Angolan state for training and supplying armaments to the country's military and offer security against UNITA [3]. Moreover, after the contract renewal with EO in 1994, government troops' accomplishment against UNITA forced the rebels to sign a peace agreement with the Angolan administration. This was a big win for the EO.

Executive Outcomes' success steered a group of British-based entrepreneurs to its control. They formed a conglomerate of associated military enterprises, for example, Ibis Air, Alpha 5, Saracen International, Teleservices International, Lifeguard, Bridge International, Shibata Security [36]. And also, resource extractions organisations, for example, Branch Energy, Heritage Energy, Ranger Oil, Diamond Works [36]. The establishment of the consortium of associated military enterprises and resource extractions organisations had one objective for the entrepreneurs, the control and extraction of the oil reserves in Angola.

The article "Warrior for hire in Iraq" describes that the ten-leading commercial, military organisations spent a further 32 million US dollars lobbying. They also spent an extra 12 million US dollars on political campaign contributions [34].
Commercial, military organisations, are not only selling their services to countries, but they are also serving as security operators for aid organisations [35]. There are no natural limitations for commercial, military organisations as to whom they may sell their services.

As already mentioned earlier, the armaments producing organisations do not make a profit by the mere fact of selling their services and products. Selling would mainly result in stockpiling, and stockpiling does not give assurance to future trade. The weapons have to be used to fight wars, whereby both conflicting parties will have stockpiled enough. If both sides are peaceful and not equipped yet, the wantrepreneurs will create a conflict and divide them.

During the 1980-88 Iran-Iraq war, the USA government often insisted on neutral in the protracted war. However, the Reagan government discretely resolved moments after taking office in January 1981 to permit Israelis, bitter foes of Saddam Hussein, to supply numerous billion dollars' worth of USA manufactured weapons as well as spare parts to Iran [15]. That intervention and the resolve to assist Tehran aided Tehran to disregard initial expectations of a rapid Iraqi triumph and attain significant achievements early in the conflict, which had commenced with an Iraqi assault in September 1980.

In 1982, the Reagan Administration secretly resolved to hand over highly classified information to President Saddam Hussein. They also authorised the trade of USA-made weapons of war to assist Iraq in forestalling an impending loss in the conflict with Iran. The USA decision to supply pivotal help to Baghdad was reached after the USA intelligence organisations cautioned that Baghdad was on the brink of being overrun by Tehran, whose military had been reinforced the year earlier by clandestine cargoes of the USAmade weapons [15]. Washington also "looked the other way," as USA-made weapons were being flown to Iraq from Baghdad's partners in the Middle East, as from 1982. Saudi Arabia and Jordan shipped small guns and mortars, amongst other arms, to Iraq, whereas Kuwait traded thousands of TOW anti-tank ammunitions with the Iraqis. By 1982, the Jordanian armed force was consistently deviating USA-made Huey helicopters for Baghdad [15].

The USA officials made no effort to stop these transfers, although the USA export law forbade the third organisation relocation of USA-made 
weapons without the USA's authorisation. Thus, the Americans were supplying both parties to see neither party domineer the strategic oil region. And by just firing these weapons and using the vast of other hardware, it amounted to revenues in unimaginable ways that helped reduce the USA government stock and aided in further production by its military producing firms.

It can be argued that the US's presence in Afghanistan had as much to do with the survival of Bush in the 2005 general election after the 9/11 attack dented his image as a president who had not protected the US from a severe home attack. By attacking and toppling the Taliban government, Bush was portraying machoism to America as the right man needed to finish the job of going after criminals everywhere and making America safe again. This is one of the best ways to preserve political power and war funding by keeping the citizens in continuous fright of 'terrorists' and terrorism [28]. As a result, the American citizens consented to a more significant part of government revenues funding the boundless industrialmilitary complex.

The Warfare in Afghanistan commenced on October 7 2001, with the coalition air bombardment on the Taliban and Al Qaeda forces and installations, officially launching Operation Enduring Freedom. This was in response to the 'terrorist's attack on September 11, 2001, in the United States, killing 2,977 people, excluding the $19 \mathrm{hi}-$ jackers. The military mission was to prevent future attacks on the Americans by the 'terrorists' relishing in a haven in Afghanistan. In the ensuing 17 years, the USA has suffered around 2,400 military causalities in Afghanistan [41]. The US Congress has also reserved over $\$ 132$ billion (Cost of War Update as of March 31, 2019) in support of Afghanistan since 2002, with approximately $63 \%$ of it for security [41]. This is gains from a war for the leader and their cronies and simply a business venture.

Interestingly, after the CIA tracked Osama bin Laden to the Tora Bora cave southeast of Kabul on December 3 2001, the American military leisurely engaged to capture him, as they left the operation to be undertaken by a ragtag Afghan contingent [9]. It resulted in the eventual escape of bin Laden for Pakistan. Which raises the following questions that: Would his capture have led to the end of the storyline of making America safe again and, therefore, an end to the reasons for spending billions on the military in Afghani- stan? Was the US troops less assertive role in his capture a strategy to ensure his escape? In mid2019, the American administrators were negotiating directly with the Taliban' terrorists' on countering terrorism. However, it is still vague on what type of political arrangements can contain both the Taliban and the US to the level that the former completely forsake their armed war/insurgency.

In 2003, the USA attacked Iraq under the pretence that Iraq bared a security risk to America, as it stocked weapons of mass destruction. For the reason that Baghdad sponsored terrorism against Americans. Another pretext was to save Iraqi citizens from Saddam Hussein's decade's old tyranny [23]. In the aftermath of $9 / 11$, the political elite was able to justify that war and rally the American citizens on what engagements to be involved in defeating terrorism (familiar detested foe) [24]. Assuming that some topmost leaders in the Bush government had by then resolved to oust President Saddam Hussein notwithstanding the 9/11 assault, President Bush would have found it difficult to garner any backing from the American citizens and its partners. The political resolve and the factual grounds vital to validate the warfare were absent. Nearly all the military new technology built-in terms of trillions of dollars since the 1980s, and intended to tilt any war with the Soviet Union to US advantage, had never been previously tested in a combat scenario. By introducing high-tech weapons during the operation, it was showcasing their effectiveness to their customers. This meant that their success rate in Desert Storm had to be shown to be dazzling by the western media, who had strategically been embedded in the operation.

Without a doubt, even before the dust of the warfare had settled in the gulf, arms manufacturers from Britain, France, United States, West Germany, and other countries were gathering in the Middle East to hawk their merchandise. Saudi Arabia, the biggest buyer, was interested in Apache helicopters, Abrams M1A1 tanks, AWACS radar planes, F-15 fighters, Patriot missiles, Bradley fighting vehicles, Seahawk helicopters, and multiple-launch rocket systems [1]. Israel wanted more Patriot missiles, the M-109 artillery, advanced F-15 fighter, and portable battlefield navigation systems [1]. Egypt is interested in buying the Hawk missiles, M-60 tank upgrades, and F-16 fighters [1]. And the United Arab Emirates, and so did Bahrain and Turkey, made clear that they 
would like to have the Patriot missiles and Abrams M1A1 tanks. The only political objectives accomplished were the Bush administration's arrogant determination to overthrow Saddam Hussein and prove that it could remove any government it disliked [20].

And the results indicate that, for the first time since 2002, the five top positions in the Global arms industry rankings are solely held by weapons organisations established in the USA: General Dynamics, Northrop Grumman, Boeing, Lockheed Martin and Raytheon. These five organisations exclusively accounted for $\$ 148$ billion and 35 per cent of total Top 100 arms sales in 2018 [37]. Total arms sales of the USA organisations totalled $\$ 246$ billion, a corresponding of 59 per cent of all weapon transactions by the Top 100 Global arms organisations. That was a 7.2 per cent increase compared with 2017.

In September 2015, Russia intervened in the Syrian civil war surprising its own nearest commentators of Moscow's overseas and security strategy. It had persistently been held that the Russian armed force would not possibly be mobilised to involve in excursion assignments beyond Russia's closest vicinity of the post-USSR. In Syria, Putin's banking on President Assad's administration was visibly important, but the indication that he would expose his military to rescue al-Assad appeared not a possibility. Yet, surprisingly, that was exactly what transpired. Therefore, it is imperative to answer why Putin would engage in such an adventure regarding this action.

The collective weapons trades of the 10 Russian organisations during the 2018 grading were $\$ 36.2$ billion, a minimal reduction of 0.4 per cent in 2017 [39]. This was an arms trade fall from 9.7 per cent in 2017 to 8.6 per cent in 2018. This could be partly related to the considerable development in the collective weapons sales of the USA and European organisations in 2018. The arms manufacturers in the USA and Europe were doing something right that the Russians had not been doing, and that is, they had successfully showcased and sold their weapons in various war theatres, but Russia had not.

Commentators had predicted a heightened danger of an accidental clash between the Russian Aerospace Forces (VKS) and the United States Airforce (USAF) over a congested Syria's airspace [7]. Nevertheless, Russian planners considered the USA presence in the Syrian theatre, and Russia was assured that the allied jets would not ag- gressively challenge their presence. Let us make a quick rewind to bring everything into focus. As of 2003, Trump was in extremely distressed financial difficulty, and his enterprises were collapsing. In 2004, Casino Resorts and Trump Hotels applied for bankruptcy with a debt of 1.8 billion dollars [16]. He couldn't get anyone in the USA to bail him. That is when the Russian 'intelligence' picked up the scent, and Trump's bailout was all coming out of Russia. His association with Moscow is more profound than ever recognised, and all with Putin's approval. Hence, Trump eventually made a comeback, particularly with investment by affluent citizens of Russia and the former USSR republics. The Russian intervention in the Syrian civil war was likely an invite of an ally to undertake some warpreneurship. Therefore, there was no way going to be a risk between Putin's and Trump's pawns.

The Russian defence-industrial complex (DIC) represents a large share of Russian's GDP as a whole. Moscow's military corporation comprises approximately 1,500 enterprises comprising research institutions, design bureaus, and production complexes acquired from the former USSR. As of 2014, the DIC comprised 1,339 organisations, engaging 1.3 million persons. The overall expenditure on security hardware and research and development amounted to approximately $\$ 45.4$ billion, or $3.4 \%$ of Russian GDP [4]. With the increasing contest in the weapons market and the development of new actors, Russian's main interest is to safeguard its current prevailing place. In part, the market launch of fresh innovations of weapons in Syria means that Kremlin can count on it. So, the Syrian conflict was used as a live-fire testing range for a new generation of Russian weapons and operational techniques. This was made evident by systematic deployments of every type of combat aircraft in the Russian catalogue, including modern Russian attack helicopters Ka-52s, Mi-35Ms, Mi-28Ns, and Su-25SM, Su-24 Su-27, Su-34s, S-300VMD and S400 anti-air missile systems, strategic bombers that had previously at no time been able to fire a weapon in a war scenario.

The conflict in Syria has had an excellent repercussion on the Russian weapons industry. The conflict has worked as a testbed and as an audition for new Kremlin military accessories. As a result, Russian arms wantrepreneurs have been able to get new equipment orders, including the S400 anti-aircraft missiles for Turkey, Saudi Arabia and India. 
On October 14, 2011, the Kenya Defense Force (KDF) invaded Somalia. It was alleged that AlShabaab was to be blamed for the decline of a security, the spillover of skirmishes into neighbouring territories, particularly in Kenya, and the severe humanitarian condition persisting in several places of Somalia [28]. However, Kenya had developed to be a target for 'terrorist' assaults even before the advent of Al-Shabaab. August 7 1998, the bombing of the American Embassy in Nairobi with a death toll of 213 people and 4,000 wounded [22]. Therefore, Kenya embarked on heavy military spending that was informed by the need to defend its territory against the Somalia-based Al-Shabaab' terrorists' who had targeted civilians and security agencies in significant towns and border townships in the past.

Surprisingly, after the KDF incursion into Somalia, during 2011-2012, Kenya has been attacked approximately 17 times, with the usages of grenades and other explosive devices. Close to 48 people have perished in these assaults, and approximately 200 people injured [22]. The targets have included churches, police agents, infrastructure, bars and nightclubs, a downtown building of small shops, learning institutions, and a bus station. This points to a deteriorating security situation in Kenya despite its military operation in Somalia that was supposed to make Kenya even safer. Instead, it is a military operation that has seen the country spend immensely on military equipment to the extent that it is alleged to be in an arm's race with the neighbours [31]. It can be argued that the main reason for the continuing Al-Shabaab attacks in Kenya is not because the Kenyan security agents are unable to curb them, but for some of the leaders to preserve power and funding for war by keeping the public in perpetual fear. As a result, they can justify to the citizens the much-increased military financing. These new wars have nothing nationalism, but they are made to create good business for some leaders and their associates.

As informed by the Stockholm International Peace Research Institute (SIPRI), Kenya acquired 186 million dollars' worth of current military weapons in five years between 2010-2015, in comparison to 8.6 million dollars' expenses between 2005-2009 which was a $20 \%$ increase during the season and the uppermost in East Africa [31]. Military imports by Kenya increased significantly, and in 2007-11, it acquired $32 \mathrm{WZ}$ 551 APCs and 4 Z-9WA helicopters from China, 15 second-hand F-5E combat aircraft from Jor- dan, 35 Puma M-26 APC from South Africa valued at Sh1.6 billion that are immune to an explosion from land mines and improvised explosive devices (IED) and $3 \mathrm{Mi}-171$ helicopters from Russia [18]. The stockpile also includes the largest vessel in the Kenya Navy fleet at 43 million dollars' naval ship from Spain christened KNS Jasiri [18]. During the 2013-17 period, it acquired two second-hand combat helicopters, 13 transport helicopters, a small number of self-propelled howitzers and 65 light armoured vehicles [43].

In addition, Kenya was diverting weapons supplied by Ukraine to South Sudan, which was still under the European Union arms embargo. The deliveries and satellite images show that some T72 tanks were delivered to Southern Sudan via Kenya [17]. Despite the USA being convinced that arms have been diverted to Southern Sudan by Kenya and Ukraine, the USA did not call for international sanctions against either country. And security commentators have concluded that Kenya was acting on the behest of the Americans. The USA was interested in ensuring that Ukraine could earn foreign exchange and increase its coffers which was being depleted due to the crisis it was having with Russia. Once in Southern Sudan, war machinery was deployed to fight an enemy who was no longer Sudan. Hence a new enemy had to be created, where vice president Riek Machar comes into the picture. Where there is a lack of a definite enemy, one has to be created to justify the usage of the war machinery. The wantrepreneurs and their cronies will propagate and influence patriotic and racial war-soliciting to inspire the citizen's backing to make big dollars in profits.

In 2017, Kenya obtained an undisclosed quantity of AH-1 cobra assault helicopters as the quota of its armed forces collaboration with Jordan [29]. Nairobi also obtained its closure of two Huey II helicopters [29]. The crafts are powered by new Honeywell T53-L-703 engines, qualifying them to have an enhanced hover performance in hot environments, reflecting KDF's requirements in its Somalia operation. The Sipri report illustrates that, in 2017, Kenya procured a second-hand maritime gun, AK-630 30mm, from Montenegro to upgrade Jasiri OPV (offshore patrol vessel). This is supposed to also meant to keep AlShabaab at bay from preying on the seagoing vessels. In February of the same year, the Kenya Navy obtained the closure of six metal shark patrol boats [29]. Additional four were supplied over last year, the cost totalling $\$ 4.9$ million. 
Kenya's armed forces expenditure in 2018 rose as it received several MD 530F armed light helicopters from US-based MD Helicopters costing $\$ 253$ million, whose orders had been placed in May 2017 [29]. The order from Nairobi included the provision of MD 530F "cayuse warrior" light assault helicopters, 24 M260 rocket launcher systems, 24 HMP 400 machine gun pod systems and assorted ammunition [29]. Bell Helicopters is to deliver to Nairobi and Kampala with 13 helicopters and spare parts. These neighbours intend to adapt to enhance their expeditions under the African Union Mission in Somalia (AMISOM) command. Al-Shabaab militants are a terrorist organisation whose mention gives legitimacy for the ruling elite to engage in warpreneurship. All this is good business for the warpreneurs and the countries' leaders engaged in it for more than just their political survival and growth.

Kampala's rendezvous in Somalia can contend as the most contemporary illustration of the Museveni regime's multi-pronged 'image management' approach to obtaining favourable relations with backers. The mission's first troops, 1,650 Ugandan peacekeepers, were deployed in March 2007. In so doing, the regime has been able to sanctify itself in the eyes of the warpreneurs. In 2014 and 2015, it procured arms from Romania, Slovakia and Bulgaria, then sent them to Juba's government, breaching the European Union weapons embargo in 2011.

Ammunition in two truckloads was transported to South Sudan from Uganda in June 2016 [29]. Later that same year, the South Sudan military obtained truckloads of small arms ammunition and two fighter jets. It is still a mystery how the two L39 jets that Kampala from Ukraine procured showed up in the Juba government, but it is a lesson learned and then perfected from her neighbour Kenya. In 2017, confidential reports claimed that the Uganda government had purchased weapons from Russia and transferred them to the South Sudan military. The 40 delivery was made of 31 tons of magazines, AK-47 rifles and assorted weapons.

In September 2017, the armed force of Uganda in Amisom received 19 Acmat Bastion armoured carriers from the USA. And in February 2018, they also got a supply of an undetermined quantity of uncrewed aerial vehicles (UAVs) for reconnaissance, surveillance and intelligence. In addition, Uganda expected and received five helicopters from the United States in 2018 as part of an \$87.6 million arrangement with Bell Helicopters endorsed in September 2016. The arms from the United States manufacturers have been made possible due to Kampala joining the bandwagon of the 'Axis of Virtuous' (the opposite of the Axis of Evil) by fighting a terrorist group Al-Shabaab.

\section{CONCLUSIONS}

But what is evident with the new wars is that they have to be given more lease of lifelike, 'Axis of Virtuous' because it is good for business. The 'Axis of Virtuous' is a highly placed ruling elite who understand the potential of warpreneurship. Gains from a war for the leader and their cronies would be simply a business venture. Believing we are under constant threat of the unseen, we become willing and dedicated sponsors to the financial and political ideas of the monstrous war industry, marketed to us under the guise of our security and protection. War does not result in peace but immense profits and securing resources for the dominant elite few.

\section{REFERENCES}

1. Adams, J. (1991). The Arms Trade: The Real Lesson of the Gulf War. Retrieved from https://www.theatlantic.com/past/docs/politics/defense/dpadams1.htm

2. Barber, N. (2013). Living through World War I. London: Raintree.

3. Baum, J. A. C., \& McGahan, A. (2009). Outsourcing War: The Evolution of the Private Military Industry after the Cold War. SSRN Electronic Journal. doi: 10.2139/ssrn.1496498

4. Bitzinger, R., \& Popescu, N. (2017). Defence industries in Russia and China: players and strategies. Retrieved from https://www.iss.europa.eu/sites/default/files/EUISSFiles/Report_38_Defenceindustries-in-Russia-and-China.pdf

5. Burkman, T. (2016). Japan and the League of Nations: Empire and world order, 1914-1938. Honolulu: University of Hawai'i Press. 
6. Burns, P. (2016). Entrepreneurship and small business: start-up, growth and maturity (4th ed.). New York: Red Globe Press.

7. Charap, S., Treyger, E., \& Geist, E. (2018). Understanding Russia's Intervention in Syria. Retrieved from https://www.rand.org/pubs/research_reports/RR3180.html

8. Clausewitz, H. (1989). On war. Princeton: Princeton University Press.

9. Council on Foreign Relations. (2021). The US War in Afghanistan 1999-2019. Retrieved from https://www.cfr.org/timeline/us-war-afghanistan

10. Dupuy, T. (2002). Elusive Victory: The Arab-Israeli Wars, 1947-1974. Garden City: Military Book Club.

11. Fearon, J. D., \& Laitin, D. D. (2003). Ethnicity, Insurgency, and Civil War. The American Political Science Review, 97(1), 75-90.

12. Garthoff, L. (1994). Détente and Confrontation: American-Soviet Relations from Nixon to Reagan. Washington: Brookings Institution Press.

13. Grunberger, R. (1964). Germany 1918-1945. New York: Harper \& Row.

14. Gurr, T. R., Woodward, M. R., Marshall, M. G., \& Political Instability Task Force. (2005). Forecasting instability: Are ethnic wars and Muslim countries different? Arlington: Political Instability Task Force.

15. Hersh, S. M. (1992). US Secretly Gave Aid to Iraq Early in Its War Against Iran. The New York Times. Retrieved from https://www.nytimes.com/1992/01/26/world/us-secretly-gave-aid-to-iraqearly-in-its-war-against-iran.html

16. Hirsh, M. (2018, December 21). How Russian Money Helped Save Trump's Business. Retrieved from https://foreignpolicy.com/2018/12/21/how-russian-money-helped-save-trumps-business/

17. Holtom, P. (2011, February). Ukrainian Arms Supplies to Sub-Saharan Africa. Retrieved from https://www.sipri.org/sites/default/files/files/misc/SIPRIBP1102.pdf

18. Holton, P., Bromley, M., Wezeman, P., \& Wezeman, S. (2012, March). Trends in International Arms Transfers, 2011. Retrieved from https://www.sipri.org/sites/default/files/files/FS/SIPRIFS1203.pdf

19. Jackson, M., \& Morelli, M. (2009, December). The Reasons for Wars - An Updated Survey. Retrieved from https://web.stanford.edu/ jacksonm/war-overview.pdf

20. Jervis, R. L. (2003). The Confrontation between Iraq and the US: Implications for the Theory and Practice of Deterrence. European Journal of International Relations, 9(2), 315-337. doi: $10.1177 / 1354066103009002006$

21. Kaldor, M. (2013). New and Old Wars: Organised Violence in a Global Era (3d ed.). Oxford: Wiley.

22. Kenya National Commission on Human Rights. (2017). Report on securing national security \& protection of human rights. Retrieved from

http://knchr.org/Portals/0/CivilAndPoliticalReports/Securing\%20National\%20Security\%20an d\%20Protection\%20of\%20Human\%20Rights.pdf?ver=2017-06-29-161740-953

23. Lecamwasam, N. (2013, June 6). Iraq Invasion: A "Just war" or Just a War? Retrieved from https://www.e-ir.info/2013/06/06/iraq-invasion-a-just-war-or-just-a-war/

24. Malang, B. (2016). The Hidden Agenda Behind the Invasion of Iraq: The Unjust War Over Iraq in 2003. Central European Journal of Politics, 2, 1-14.

25. Mello, P. A. (2010). Review article: In search of new wars: The debate about a transformation of war. European Journal of International Relations, 16(2), 297-309. doi: $10.1177 / 1354066109350053$

26. Morelli, M., \& Rohner, D. (2010). Natural Resource Distribution and Multiple Forms of Civil War. Zurich: Institute for Empirical Research in Economics. 
27. Mueller, J. (2004). The remnants of war. Ithaca: Cornell University Press.

28. Mutonyi, G. P. (2020). From Old Wars, To New Wars. Path of Science, 6(6), 9001-9011. doi: $10.22178 /$ pos.59-10

29. Olingo, A. (2018, March 17). Uganda tops East Africa in military hardware expenditure. Retrieved from https://www.theeastafrican.co.ke/tea/news/east-africa/uganda-tops-east-africa-inmilitary-hardware-expenditure-1386300

30. Palmer-Fernandez, G. (2003). The march to war: from missile defense to preemptive war. Retrieved from https://www.coursehero.com/file/46694469/Iraq-War-of-2003pdf/

31. Perlo-Freeman, S., Fleurant A., Wezeman, P., \& Wezeman, S. (2016, April). Trends in world military expenditure, 2015. Retrieved from https://www.sipri.org/sites/default/files/EMBARGO\%20FS1604\%20Milex\%202015.pdf

32. Seifert, T., \& Werner, K. (2007). Het zwarte goud: Olie als bron van hebzucht, oorlog: olie als bron van hebzucht, oorlog, macht en geld. Rijswijk: Uitgeverij Elmar.

33. Shane, S., \& Venkataraman, S. (2000). The Promise of Enterpreneurship as a Field of Research. The Academy of Management Review, 25(1), 217. doi: 10.2307/259271

34. Singer, P. (2004, April 15). Warriors for hire in Iraq. Retrieved from https://www.brookings.edu/articles/warriors-for-hire-in-iraq/

35. Singer, P. (2004, March 1). War, Profits, and the Vacuum of Law: Privatised Military Firms and International Law. Columbia Journal of Transnational Law, 42(2), 521-550.

36. Singer, P. (2008). Corporate Warriors: The Rise of the Privatized Military Industry. Ithaca: Cornell University press.

37. SIPRI. (2019, December 9). Global arms industry rankings: Sales up 4.6 per cent worldwide and US companies dominate the Top 5. Retrieved from https://www.sipri.org/media/pressrelease/2019/global-arms-industry-rankings-sales-46-cent-worldwide-and-us-companiesdominate-top-5

38. Smith, A., \& Stam, A. C. (2004). Bargaining and the Nature of War. The Journal of Conflict Resolution, 48(6), 783-813.

39. Steinberg, J. (2013). Bismarck: A Life. Oxford: Oxford University Press.

40. The Dalai Lamai. (1990). The Global Community and the Need for Universal Responsibility. Retrieved from https://www.lamayeshe.com/article/global-community-and-need-universalresponsibility

41. Thomas, C. (2020, June 25). Afghanistan: Background and US Policy: In Brief. Retrieved from https://fas.org/sgp/crs/row/R45122.pdf

42. Wennekers, S., \& Thurik, R. (1999). Linking Entrepreneurship and Economic Growth. Small Business Economics, 13, 27-56. doi: 10.1023/A:1008063200484

43. Wezeman, P., Fleurant, A., Kuimova, A., Tian, N., \& Wezeman, S. (2018, March). Trends in International Arms Transfers, 2017. Retrieved from https://www.sipri.org/sites/default/files/2018-03/fssipri_at2017_0.pdf

44. World Bank. (2011). World Development Report 2011: Conflict, Security and development. Retrieved from https://openknowledge.worldbank.org/handle/10986/4389 